was partially replaced by dry peas or urea, the latter not exceeding $\mathrm{I} .5 \%$ of the concentrate in any case;

- The problem of protein supplementation of farm cereal mixtures is not completely solved. Even if there is free access to cereals and protein feed, over-consumption of the latter is almost always the rule.

\title{
Amino acid requirements of preruminant lambs
}

\author{
P. PATUREAU-MIRAND $\left({ }^{*}\right)$ and M. THERIEZ $(* *)$ \\ $\left(^{*}\right)$ Laboratoire d'étude du métabolisme azoté, \\ (**) Station de Recherches sur l'Élevage des Ruminants, \\ Centre de Recherches de Clermont-Ferrand, I.N.R.A., \\ Theix 63IIo Beaumont (France).
}

The amino acid requirements of preruminant lambs were tentatively determined by different methods:

- ewe milk amino acids are assumed to satisfy the amino acid requirement of lambs and are compared to those of cows milk (Table I);

- the amounts of essential amino acids ingested by lambs in which the protein requirement is satisfied may be used as rough estimations of the amino acid requirements of preruminant lambs (Table 2). This method of evaluation tends to underestimate the requirements for the limiting amino acids of the experimental protein, and to overestimate the requirements for amino acids in excess of that protein.

The requirements for some essential amino acids were directly determined by measuring the nitrogen balance and /or the blood level of free amino acids of lambs fed increasing amounts of those amino acids. Thus, the methionine requirement of preruminant lambs was about $2.0 \mathrm{~g} / \mathrm{d}$ (Fig. I), i.e. $2.6 \mathrm{~g} / \mathrm{d}$ of sulphur amino acids.

The amino acid requirements of fast-growing lambs $(250$ to $300 \mathrm{~g} / \mathrm{d}$ ), evaluated by the different methods, are summarized in Table 5. It may be inferred that amino acid requirements vary according to age and feeding level. The amino acid requirements of 8 -day old preruminant lambs fed ad libitum seemed to be satisfied by $67 \mathrm{~g} / \mathrm{d}$ of cow milk protein supplemented by $0.3 \mathrm{~g} / \mathrm{d}$ of $\mathrm{DL}$ methionine and $0.9 \mathrm{~g} / \mathrm{d}$ of $\mathrm{L}$ lysine. When the lambs were $2 \mathrm{r}$ day old, they needed $72 \mathrm{~g} / \mathrm{d}$ of cow milk protein supplemented by $0 . \mathrm{g} / \mathrm{d}$ of DL methionine and $0.5 \mathrm{~g} / \mathrm{d}$ of L lysine, if fed ad libitum: $76 \mathrm{~g} / \mathrm{d}$ of cow milk protein supplemented by $0.3 \mathrm{~g} / \mathrm{d}$ of DL methionine if the feeding level was only $80 \%$ of ad libitum fecd consumption.

\section{Effect of dehydrated pelleted hay on calcium and phosphate metabolism in lambs}

\author{
J. P. BARLET \\ Station de Physiopathologie de la Nutrition, \\ Centre de Recherches de Clermont-Ferrand, I.N.R.A., \\ Theix, 63IIo Beaumont (France).
}

In 3-month-old ram lambs fed dehydrated pelleted lucerne hay, the urinary and faecal excretion of calcium was significantly higher than in control lambs fed normal lucerne hay (Table II). The causes for these differences are still unknown. This may be due to an increase in the speed 